\title{
Morphology and Lectin histochemistry of the testes of brown-banded bamboo shark (Chiloscyllium punctatum)
}

\author{
Kassab M ${ }^{1}$; Yanai $\mathrm{T}^{2}$; Ito $\mathrm{K}^{2}$; Sakai $\mathrm{H}^{2}$; Mesegi $\mathrm{T}^{2}$; Yanagisawa $\mathrm{M}^{3}$ \\ 1-Department of Cytology and Histology, Fac.Vet. Med., Kafr El- sheikh Univ., Egypt \\ 2-Department of Pathology, Fac. of Biological Science, Gifu Univ., Japan \\ 3-Okinawa Churaumi Aquarium, Japan \\ Email: kassabkassab2000@yahoo.com
}

With 22 figures

Received at August 2009, accepted for publication October 2009

\begin{abstract}
The testes of three brown-banded bamboo male sharks collected from Okinawa Churaumi Aquarium, Japan were used in this study. The testes were studied grossly and microscopically. In addition, conventional and lectin histochemistry (panel of $8 \mathrm{HRP}$ lectins, UEA-I, DBA, LCA, PNA, ConA, PHA-E4, WGA and RCA 120) were applied for studying the glycoconjugates.
\end{abstract}

The testes are suspended to the dorsal wall by mesorchium. They are covered ventromedially by the epigonal organ (Hematopoietic organ). The testis is divided into germinal, spermatogonial, spermatocytes, spermatid, spermatozoal and degenerative zones.

Analysis of the sugar binding-lectins in the shark testes revealed the presence of all sugars under investigation, although they varied in distribution throughout the different zones. The germinal zone was not labeled to any sugar, while the spermatogonial zone was labeled to galactosamine. The spermatocyte zone was labeled to glucose, galactose and glucosamine within the Leydig cells, while the spermatocysts were labeled only to the galactose and glucoseamine. The spermatocyst of the spermatide zone was similar to that of the spermatocyte zone while the Leydig cells were labeled to all sugars under investigation. The spermatozoal zone was labeled to all sugars under investigation either to the spermatocyst or to the Leydig cells. At the degenerative zone, Leydig cells were labeled to all sugars under investigation while the spermatocyst was labeled to glucose and glucosamine only.

In conclusion, our results indicate that the structure of the testes of the brownbanded bamboo shark simulate that of the cartilaginous fish. There is progressive increase in glycolsylation during spermatogenesis, especially at 
the embedding of the elongated spermatids to the Sertoli cells ( spermatoblasts) in the spermatid spermatozoa step. The Leydig cells are strongly labeled in the spermeiogenesis and degenerative zones than in the germinal, spermatogonial and spermatocyte zones due to its androgen activity.

\section{Key Words}

Lectin, testes, bamboo shark

\section{Introduction}

The brown-banded bamboo shark is a cartilaginous and tropical species found across the northern coast of Australia and the Indo-pacific north to Japan and west to the east coast of India. The Morphological data of the shark testes are studied in different species ( Matthews, 1950; Stanely, 1966; Holestein, 1969; Chen et al. 1973; Wourms, 1977; Dobson and Dodd, 1977; Teshima, 1981; Pudney and Callard, 1984 a,b; Pratt, 1988; Parson and Grier, 1992 and Girard et al. 2000). Testicular structure and spermatogenesis of the cartilaginous fishes are unique in several ways, such as cystic organization, zones arrangement of the spermatocysts and a close association of the testes with hematopoietc epigonal organ ( Dodd and Sumpter, 1984; Pratt, 1988; Hamlett et al. 1999 and Liguoro et al. 2004).

Specific carbohydrates expression patterns may exhibit striking changes related to cell differentiation (Roth
1996). Recent advances in glycan research have shown that cell surface proteoglycans are implicated in cell development and differentiation through a role in cell signaling by paracrine and autocrine factors, such as growth factors, chemokines and cytokines (lozzo, 1998; Bernfield et al. 1999; Lander and Selleck, 2000 and Kassab et al. 2007).

In the field of male fertility, lectin histochemistry is considered as a valuable method for determining changes in the glycoconjugate content during spermatogenesis under normal and pathological conditions (Wine and Chapin, 1997 and Arenas et al., 1998). In additiona, lectin histochemical analysis of the testes has allowed the staining patterns of spermatogenic cells to be visualized, thus allowing determination of the sequential glycolsylation processes of acrosome development in rats (Martinez-Menargues et al., 1999), mice (Arya and Vanhaperttula, 1986), hamsters (Ballesta et al., 1991), dogs (Montkowski, 1992), humans (Arenas et al., 1998), bulls (Ertl and Wrobel, 1992 and Abd-Elmaksoud, 2005), goats (Kurohmaru, 1991), horse (Verinisupplizi et al., 2000), boars (Pinart et al., 2001, 2002) and camel (Abd-Elmaksoud et al., 2007) .

The morphology of the shark testis is studied by several authors, although glcoconjugates of the spotted ray Torpedo marmorata was investigated (Liguoro et al. 2004), the brown-banded bamboo shark has not yet according to our knowledge. So the aim of this study is to describe the morphological struc- 
ture of the testis and the glycolconjugates of different structures and its relation to spermatogenesis in brownbanded bamboo shark.

\section{Materials and Methods}

Three brown-banded bamboo male sharks were used in this study at winter season(October-January). The sharks were collected from Okinawa Churaumi Aquarium, Japan. The sharks ranged about $100 \mathrm{~cm}$ length and $4 \mathrm{~kg}$ weight (Fig. 1). The sharks were dissected at the middle of body cavity, eviscerated and the testes were exposed. The length of the testes was measured. Cross section samples were fixed in bouin's solution for 18-24 hours at room temperature. The samples were extensively washed in $70 \%$ ethanol. Thereafter, the samples were dehydrated in graded series of ethanol (80\%, 90\%, $95 \%$ and absolute), cleared in lemosol and embedded in paraffin wax. Sections 3-5 microns thickness were mounted on uncoated and coated slides with 3-aminopropyltrieth-oxy-silane. For general histological studies, selected slides were stained with Haematoxylin and Eosin.

\section{Conventional histochemistry:}

For general description of glycoconjugates, the slides were stained with Periodic Acid Schiff (PAS) for neutral mucopolysaccharides, Alcian Blue $\mathrm{pH}$ 2.5 (AB 2.5) $\mathrm{AB}$ pH 1.0 and $\mathrm{AB} \mathrm{pH} 0.5$ for acidic mucopolysaccharides (Pearse, 1985).

\section{Lectin histochemistry:}

Lectin binding sites were demonstrated by means of horse radish peroxidase (HRP). The slides were deparaffinized, then rehydrated using descending grades of ethanol until distilled water. Endogenous peroxidase activity was blocked by incubation in $0.3 \%$ hydrogen peroxide ( $\mathrm{H} 2 \mathrm{O} 2)$ in methanol for 30 minutes at room temperature, thereafter the sections were incubated in $1 \%$ goat serum albumin (DAKO, USA) in phosphate buffer saline (PBS) for 20 minutes to minimize nonspecific staining. Subsequently, the slides were incubated with HRP conjugated lectins (J Oil Mills, Tokyo, Japan) for one hour at room temperature. Lectins were generally used at concentrations 5- 20 $\mu \mathrm{g} / \mathrm{ml}$ PBS $\mathrm{pH} 7.6$ (Table 1). All sections were washed in PBS 3 times (3x5min.). The peroxidase activity was visualized by Dako cytomation (Liquid $\mathrm{DAB}$; 3, 3' diaminobenzidine; and substrate chromogen system) (DAKO, USA) for 30 minutes at room temperature. Finally, the sections were washed in distilled water (3x5min.), counterstained with Meyer's haematoxylin, dehydrated, and mounted with Mount-Quick (Daido Sangyo co., Japan). Lectin specificities were adopted to Debray et al. (1981), Spicer and Schulte (1992) and Danguy (1995).

To examine the specificity of lectin staining, control sections were prepared by one of the following: addition of inhibitory sugars to the respective lectin solution, substitution of unconjugated lectins for the horse radish and finally the exposure of sections to Dakocytomation without lectins. 
The staining intensity was classified by two independent observers into 4 categories: no labeling (-ve), weak labeling $(+)$, moderate labeling $(++)$, and strong labeling $(+++)$.

Table 1: The lectins used and their sugars binding specificities.

\begin{tabular}{|c|c|c|c|c|c|c|}
\hline \multicolumn{2}{|c|}{ Lectin group* } & Name & Sugar binding & Concen- & Binding & Inhibitor \\
\hline \multirow{2}{*}{$\begin{array}{l}\text { Glucose } \\
\text { binding lectins }\end{array}$} & LcA & Lens culinaris & a-Man & $5 \mu / \mathrm{ml}$ & HRP & Man \\
\hline & $\begin{array}{c}\text { Con } \\
\text { A }\end{array}$ & $\begin{array}{c}\text { Concanavalin } \\
\text { A }\end{array}$ & $\begin{array}{c}\alpha-D-\text { Man>a- } \\
\text { d-Glc }\end{array}$ & $10 \mu / \mathrm{ml}$ & HRP & Man \\
\hline \multirow[t]{2}{*}{$\begin{array}{l}\text { Galactose } \\
\text { binding lectins }\end{array}$} & PNA & $\begin{array}{c}\text { Peanut } \\
\text { agglutinin }\end{array}$ & $\begin{array}{c}\text { Gal } \beta 1- \\
\text { 3GalNAC }\end{array}$ & $20 \mu / \mathrm{ml}$ & HRP & Gal \\
\hline & $\begin{array}{c}\text { RCA } \\
120\end{array}$ & $\begin{array}{c}\text { Ricinus } \\
\text { communis } \\
120\end{array}$ & $\begin{array}{c}\text { Gal } \beta 1- \\
\text { 4GlcNAC }\end{array}$ & $5 \mu / \mathrm{ml}$ & HRP & Gal \\
\hline $\begin{array}{l}\text { Glucosamine } \\
\text { binding }\end{array}$ & WGA & $\begin{array}{c}\text { Wheat germ } \\
\text { agglutinin }\end{array}$ & $\beta-D-G \mid c N A C$ & $5 \mu / \mathrm{ml}$ & HRP & GlcNAC \\
\hline $\begin{array}{l}\text { Galactosamine } \\
\text { binding }\end{array}$ & DBA & $\begin{array}{l}\text { Dolicos } \\
\text { biflorus }\end{array}$ & $\begin{array}{c}\text { GalNac } \alpha 1-3 \\
\text { GalNac }\end{array}$ & $20 \mu / \mathrm{ml}$ & HRP & GalNac \\
\hline $\begin{array}{l}\text { Fucose } \\
\text { binding lectin }\end{array}$ & $\begin{array}{l}\text { UEA- } \\
1\end{array}$ & $\begin{array}{c}\text { Ulex } \\
\text { europaeus -1 }\end{array}$ & $\alpha-L-F u c$ & $20 \mu / \mathrm{ml}$ & HRP & Fuc \\
\hline Non specific & $\begin{array}{l}\text { PHA- } \\
\text { E4 }\end{array}$ & $\begin{array}{l}\text { Phaseolus } \\
\text { vulgaris }\end{array}$ & D-GalNAC & $5 \mu / \mathrm{ml}$ & HRP & GalNAC \\
\hline
\end{tabular}

Gal : Galactose, GalNAC: N-acetylgalactosamine, Glc: glucose, GlcNAC: Nacetylglucosamine, Fuc: fucose, Man: mannose, 


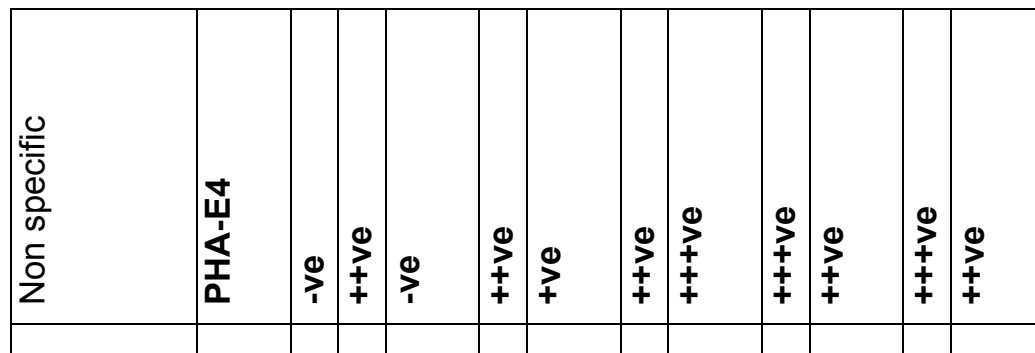

号

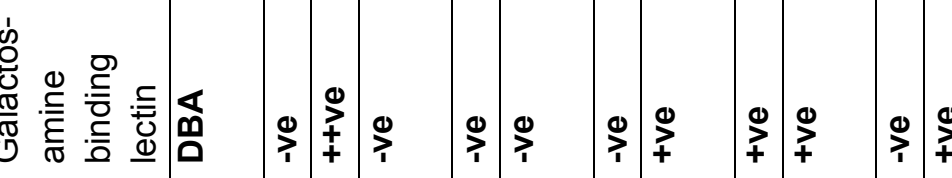

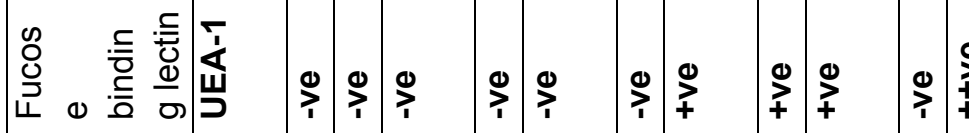

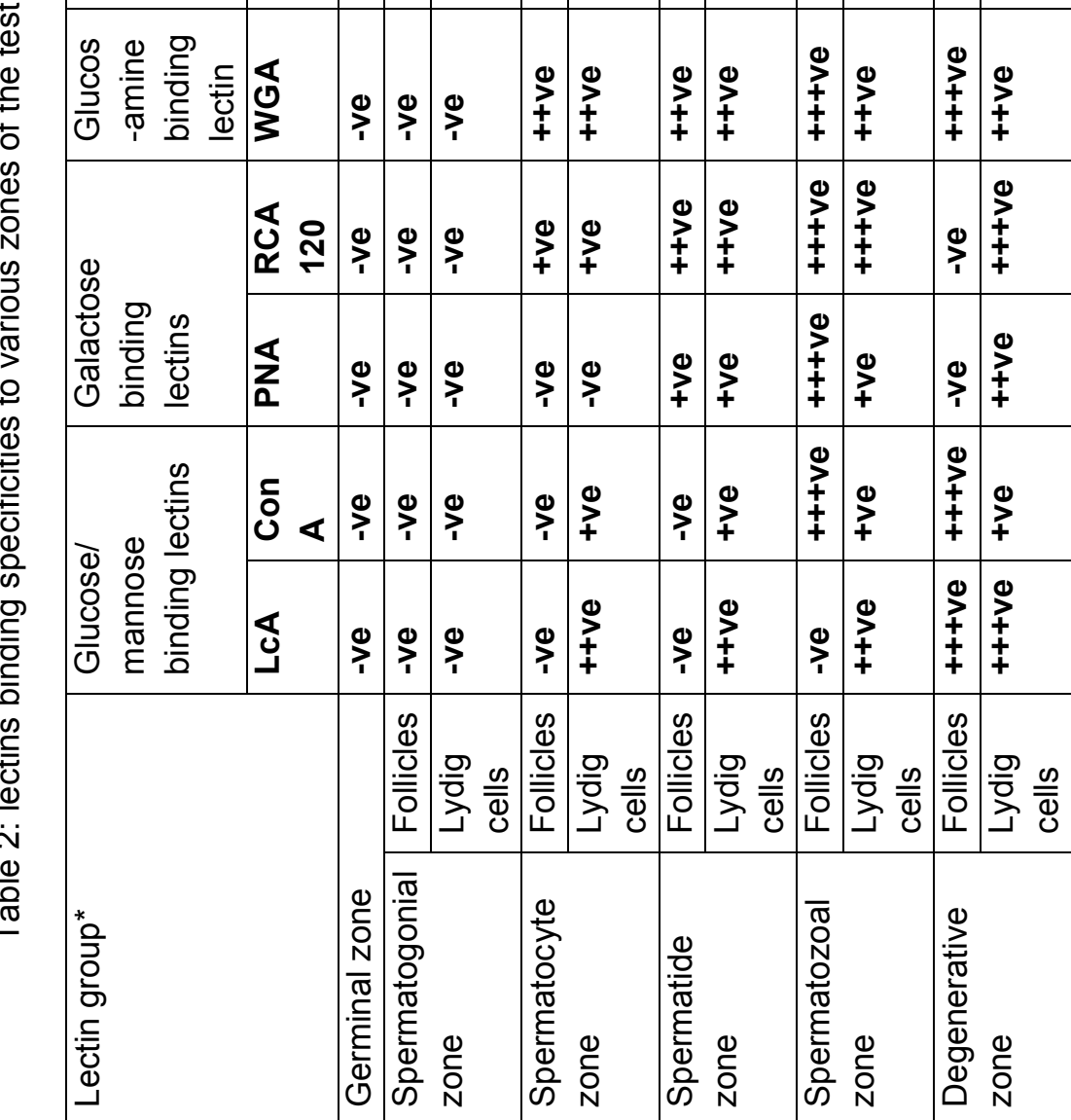




\section{Results}

The testes were suspended to the dorsal wall by mesorchium in the cranial end of the body cavity, just under the vertebral column. They were covered ventromedially by the epigonal organ (hematopoietic organ). They were measured about $7 \mathrm{~cm}$ in length. The left one is slightly longer than the right (Fig.1B). Microscopically, the parenchyma was divided into several lobes.

These lobes were clearly organized dorsally by connective tissue septae. These septae contained intratesticular ducts that lined with cuboidal epithelium. These ducts were prominent in the dorsal and ventral parts of the testis and could not be demonstrated at the middle part. Each lobe showed zones arrangement and contained numerous round- shaped spermatocysts (follicles). The zones were named germinal, spermatogonial, spermatocyts, spermatid, spermatozoal and degenerative zones (Fig.1C, D, E, F and G).

The germinal zone was located in the most dorsal part of the testis containing spermatogonium and undifferentiated Sertoli cells not organized into a definite shape (Fig.1D and E). Once these two cell types form round- shaped spermatocyst it became spermatogonial zone (Fig.1F). The mitotic division of spermatogonium continued, the Sertoli cells were located basally, to form the spermatocyts zone. Then the spermatocyts began meiotic division to form finally the spermatids zone, in which there was increment of the number of the layers in the spermatocyst, decrement of the size of the cells with dark nuclei. The spermatids then inter the process of spermeiogenesis which started by elongation of the nuclei with the formation of the acrosome, then all the spermatids overlie the Sertoli cells and imbedded in it forming together the spermatoblast which characterized by PAS positive granules (Fig. $1 \mathrm{G}$ and $\mathrm{H}$ ). After complete transformation of the spermatids to spermatozoa, the spermatozoal spermatocysts evacuate their spermatozoa into the intratesticular ducts and the remnant of the spermatocysts underwent degeneration with prominent PAS positive materials in the degenerative zone which occupied the most ventral part of the testis in relation to the epigonal organ. All the previous zones were negative to the $A B$ with different $\mathrm{pH}$. The Leydig cells were few in the spermatogonial zone and then increased in numbers to appeared more in the spermatids and spermatozoal zones (Fig. 1C, F, G and $H)$. The glycoprotein histochemistry was expressed mainly on spermeiogenesis zones (spermatids and spermatozoal), and degenerative zone (table 2).

Germinal zone showed no labeling to all lectins under investigation. Spermatogonial zone showed moderate labeling to $\mathrm{N}$-acetyl-galactosamine as observed by DBA and PHA. The reaction was labeled to the nuclei (Fig. 2A).

The spermatocyte zone labeling differed from spermatocyst to the Leydig cells and interstitial tissue. Spermatocysts showed galactose, $\mathrm{N}$ acetyleglucosamine as labeled by RCA, 
WGA and PHA, while the interstitial tissue containing Leydig cells showed mannose, galactose and $\mathrm{N}$-acetylglucosamine as described by LCA, ConA, RCA, WGA and PHA.

The spermatids spermatocyst were positive for galactose, $\mathrm{N}$-acetyl glucosamine as observed by PNA, RCA, WGA and PHA. The Leydig cells contained mannose, galactose, $\mathrm{N}$ acetyl glucosamine, fucose and $\mathrm{N}$ acetylgalactosamine as described by all lectins under investigation (Fig. 2B,C and D).

The spermatozoal zone showed strong labeling to most lectins under investtigation either in spermatocysts or Leydig cells. The sperms differentiate according to labeling into head, tail and the junction with the Sertoli cells. The head showed reaction to all lectins except LCA, while the tail was not labeled with LCA and ConA and labeled to the others (Figs. $2 \mathrm{E}, \mathrm{F}, \mathrm{G}, \mathrm{H}$ and 3 A).

In the degenerative zone, where the spermatocysts evacuate their sperms to the intratesticular duct, the remainder of the follicles underwent degeneration and their was high expression to mannose, glucosamine as observed by LCA, ConA, WGA and PHA. The Leydig cells showed labeling to all lectins under investigation (Figs. $3 \mathrm{~B}, \mathrm{C}, \mathrm{D}, \mathrm{E}$ and $F$ ).

\section{Discussion}

The testes of the brown-banded bamboo shark are like the diametric type stated by Pratt (1988), who added that the germinal zone is nested among the origin of the trabeculae. The seminiferous follicles development spreads from this zone across the diameter of the testis toward the opposite wall, where the efferent ductules are present to receive spermatozoa (Stanley, 1966). The displacement of the spermatocysts is not active movement for each, but they are passively replaced by the newly formed ones (Parson and Grier, 1992 and Chatchavalvanich et al. 2005). The intratesticular ducts are clearly visible in the germinal and spermatogonial zones but are rarely seen in the spermatocyte, spermatid and spermatozoal zones because the increases of spermatocysts size obscure them. These ducts can be clearly seen again in the degenerative zone, as the spermatocysts became small and had undergone degeneration even as the duct becomes more developed (Chatchavalvanich et al. 2005).

Apparently the acrosomal structure in spermatid and the Sertoli-spermatid attachment are positive to the neutral mucopolysaccharides as indicated by PAS. These results are in accordance to that of mammalian species, but unlike that of fresh water stingray and other non mammalian species as frog, cobra and avian which are negative to PAS stain (Gunawardana, 1977; Aire et al., 1980 and Chatchavalvanich et al., 2005). 
Lectins have a specific binding affinity for the sugar residues of glycolconjugates, therefore they are used as histochemical reagents to investigate the distribution of glycol-conjugates in various tissues including testis (Arya and Vanha-perttula,1985, 1986; Lee and Damjanov, 1984; Soderstrom et al., 1984; Wollina et al., 1989; Malmi et al., 1990; Ballesta et al., 1991; Kurohmaru, 1991; Ertl and Wrobel, 1992; Montkowski, 1992; Arenas et al., 1998; Martinez-Menargues et al., 1999; Verinisupplizi et al., 2000, Pinart et al., 2001, 2002; Abd-Elmaksoud, 2005). In our study, the sugar residues of glycoconjugates in bambooshark testis were investigated using eight (ConA, LCA, PNA, DBA, PHA, WGA, UEA-I and $\mathrm{RCA}$ ) horse radish peroxidase (HRP) lectins. Detection of sugar moieties by lectins was carried out in winter season. Careful analysis of sugar binding-lectins in the shark testes revealed the presence of all sugar under investigation but their distributions were varied according to the zones of the testes. The germinal zone was not labeled to any sugar while the spermatogonial zone was labeled to the galactosamine. The spermatocyte zone was labeled to glucose, galactose and glucosamine in the Leydig cells, while the spermatocyst was labeled only to the galactose and glucosamine. The spermatocyst of the spermatide zone was like that of the spermatocyte zone while the leydig cells were labeled to all sugars under investigation. The spermatozoal zone was labeled to all sugars under investigation either to the spermatocyst or to the Leydig cells. The
Leydig cells in the degenerative zone were labeled to all sugars under investigation, while the remnant of spermatocysts was labeled to glucose and glucosamine only.

Our results showed that, some germ cells in the spermatogonial zone were labeled to galactosamine indicating apoptosis. This reaction could be attributed to, during apoptosis, the cellular surface composition changes like apoptotic hepatocytes with increased GalNAC and galactose, making the cells susceptible to phagocytosis (Dini et al 1992), on the other hand, the presence of galactosamine NAc on the spermatogonia might induce in the onset of meiosis within the cysts and the germ cells lose the ability to divide mitotically and become able to divide meiotically ( Liguoro et al. 2004).

After formation of spermatoblasts, positive labeling to most lectins under investigation is evident on the germ and Sertoli cells. The positive reaction may be due to the presence of glycolproteins, like cadherin, that contain mannosyle chains available to establish interactions between germ and somatic cells (Liguoro et al. 2004). In this regard, it is noteworthy that in mammals a unique oligosaccharide containing mannosyle residues was identified within germ cells to adhere to Sertoli cells (Akama et al. 2002).

Interestingly, after spermiation, the Sertoli cells were positive and strongly labeled more than in the early glandular tissue, indicating that, these 
sugar residues could be attributed to either spermiation related functional changes or the start of the degenerative process ( Saez et al. 2001a,b). The strong staining of the degenerative zone specially the evacuated cysts may be due to the residual spermatides cytoplasm in the cytoplasm of Sertoli cells by phagocytosis, as reported in mammals (Arya and Vanha-Parttula 1985, Verini-Supplizi et al. 2000).

It is widely accepted that glycolconjugates are involved in cell differentiation (Zaik et al. 1996). Recently it has been shown that glycosaminoglycans of the cell surface proteoglycans are involved in controlling cell differentiation and proliferation by binding to local mediators as fibroblast growth factor (FGF), hepatocyte growth factor (HGF), epidermal growth factor (EGF) require heparin sulphate for high affinity binding to their receptors (Bernfield et al. 1999, Lander and Selleck 2000). In addition, binding of transforming growth factor (TGF $\beta$ ) to heparin sulphate prevent its activation ( Carreau 1996, MendisHandagama 1997, Hedger and de Kretser 2000). Recently it has been shown that some growth factors as insulin like growth factor (IGF) activate, while TGF $\beta 1$ inhibit testosterone synthesis and leydig cell differentiation ( Bentone et al. 1995, le Roy et al. 1999). It is possible to speculate some possible roles for carbohydrate chains in the differentiation of steroid hormone secreting cells. The distribution of lectins binding sites significantly changes within Leydig cells. The labeling of lectins to the Leydig cells was significant in the spermiogenesis zones (spermatids, spermatozoal) and degenerative zone than in the spermatogonial and spermatocyte zones, which indicate great changes in spermatogenesis due to its androgen activity.

In conclusion, our results indicate that the structure of the testes of the brownbanded bamboo shark is like that of the cartilaginous fish. There is progressive increase in glycolsylation during spermatogenesis, especially at the elongated spermatids and Sertoli cells( spermatoblasts) in the spermatidespermatozoa step. The Leydig cells are strongly labeled in the spermeiogenesis and degenerative zones than in the germinal, spermatogonial and spermatocyte zones due to its androgen activity.

\section{Acknowledgments}

The authers thank the Matsumae International Foundation for its support to Dr. Mohamed kassab in his fellowship to Gifu Univ., Japan.

\section{References}

Abd-Elmaksoud, A. (2005):

Morphological, Glycohistochemical, and Immunohistochemical Studies on the Embryonic and Adult Bovine Testis. Thesis, Institute of Veterinary Anatomy II, Faculty of Veterinary Medicine, LMU ,Munich, Germany

Abd-Elmaksoud A, Sayed-Ahmed A, Kassab M and Aly K (2007): Histochemical mapping of glycoconju-gates in the testis of the one humped camel 
(Camelus dromedarius) during rutting and non-rutting. Acta Histochemdoi:10.1016/ j.acthis.2007.10.004

Aire TA, Olowo-Okorun MO and Ayeni JS (1980): The seminiferous epithelium in the Guinea fowl (Numida meleagris). Cell tissue Res 205, 319-325

Akama T.O., Nacagawa H., Sugihara K, Narisawa S.,Ohyama C., Nishimura SI., O"Brien DA., Moremen KW., Millan JL and Fukuda MN. (2002): Germ cell survival through carbohydrates-mediated interaction with sertoli cells. Science 295, 24-127

Arenas, M. I., Madrid, F.R.

Bethencourt, B. Fraile, and A.Paniagua,(1998):

Lectin histochemistry of the human testis. Int. J. Androl. 21, 332-342.

Arya, M., and Vanhaperttula T. (1985): Lectin binding pattern of bull testis and epididymis. Journal of Andrology 6, 230-232

Arya, M., and Vanha-perttula T. (1986): Comparison of lectin-staining pattern in testis and epididymis of gerbil, guinea pig, mouse, and nutria. Am. J. Anat. 175, 449-469.

Ballesta, J., Martinez-Menarguez J.A., Pastor L.M., Aviles M., Madrid J. F. and Castells M.T. (1991): Lectin binding pattern in the testes of several tetrapode vertebrates. Eur. J. Basic Appl. Histochem. 35,107-17

Benton L, Shan LX, Hardy MP (1995): Differentiation of adult Leydig cells. Journal of steroid Biochemistry and Molecular Biology 53, 61-68

Bernfield M, Gotte M, Park PW, Reizes

$\mathrm{O}$, Tzgerald $\mathrm{ML}$ and
Lincecum J. (1999): Functions of cell surface heparin sulphat proteoglycans. Annual Reviews of Biochemistry $68,729-777$

Carreau S (1996): Paracrine control of human Leydig cell and Sertoli cell functions. Folia Histochemica et Cytobiologica 34, 111-119

Chatchavalvanich $\mathrm{K}$, Thongpan $\mathrm{A}$ and Nakai M (2005): Structure of the testis and genital duct of fresh water stingray, Himantura signifier (Elasmobranchii: Myliobatiformes: Dasyatidae).Ichthyol Res 52, 123131

Chen CT, Teshima $\mathrm{K}$ and Mizue $\mathrm{K}$ (1973): Testes and spermatogenesis in selachians. Bull Fac Fish Nagasaki Univ 35:35-65

Danguy A. (1995); Perspectives in modern glycolhistochemistry. Eur. J. Bas. Appl. Histo chem. $39,5-14$.

Debray H, Decout D, Strecker G, Spik J and Montreuil J. (1981): Specificity of twelve lectins to wards oligosaccharides and glycopeptides related to $\mathrm{N}$ glycosylprotiens. Eur. J. Bio chem., 117, 41-55.

Dini L., Autori F., Lenteni A., Oliverio S and Piacentini M (1992): The clearance of apoptotic cells in the liver is mediated by asialoglycoprotein receptor. FEPS Lett 296: 174-178.

Dobson S and Dodd JM (1977): Endocrine control of the testes in the dogfish Scyliorhinus canicula L. II Histological and ultrastructural changes in the testes after hyperphysectomy (venteral lobectomy). Gen Comp Endocrinal 32:53-71 
Dodd JM and Sumpter JP (1984): Fishes, In: Lamming GE (ed) Marshall*s physiology of reproduction, Vol 1. Churchill Livingstone, Newyork, pp 1126

Ertl, C., and. Wrobel K. H (1992): Distribution of sugar residues in the bovine testis during postnatal ontogenesis demonstrated with lectin-horseradish peroxidase conjugates. Histochemistry. 97, 161-71.

Girard M, Rivalan P and Sinquin G (2000): Testes and sperm morphology in two deepwater squaloid sharks, Centroscymnus ceololepis and Centrophorus squamo-sus. J Fish Biol 57: 1575-1589

Gunawardana VK (1977): Stages of spermatides of the domestic fowl: a light microscopic study using Araldite sections. J Anat 123, 351-360

Hamlett WC, Hysell M, Brunette N, Tumilty $\mathrm{K}$, Henderson $\mathrm{A}$ and Dunne J (1999): Sperm aggregation and spermatozeugmata formation in the male genital ducts in the clearnose skate, Raja eglanteria. In Sert B, Sire JY(eds) Proceeding, $5^{\text {th }}$ IndoPacific Fish Conference. OSRAM, Paris, pp 281-291

Hedger MP and De Kretser DM (2000): Leydig cell function and its regulation. Results and Problems. Cell Differentiation 28, 69-110

Holstein AF (1969): Zur Frage der Lokalen Steuerung der spermatogenese beim Dornhai (Squalus acanth-ias L). Z. Zellforsch Mikrosk Anat 93: 265-281
Iozzo RV (1998): Matrix proteoglycans: from molecular design to cellular function. Annual Review of Bio-chemistry 67, 609-652.

Kassab M., Abd-Elmaksoud A and Mona A. Ali (2007): Localization of the epidermal growthfactor (EGF) and epidermal growth factor receptor (EGFR) in the bovine testis. J Mol Hist, 38:207-214

Kurohmaru, M. (1991): Lectin-

binding patterns in the spermatogenic cells of the shiba goat testis. J. Vet. Med. Sci. 53, 893-897.

Lander AD and Selleck SB (2000): The elusive functions of proteoglycans: in vivo VERITAS. Journal of Cell Biology 148, 227-232

Le Roy C, Le Jeune H, Chuzel F, Saez JM and Langolis D (1999): Autocrine regulation of Leydig cell differentiation functions by insulin like growth factor 1 and trans-forming growth factor beta. Journal of Steroid Biochemistry and Molecular Biology 69, 379-384

Lee MC and Damjanov I. (1984): Anatomic distribution of lectin binding sites in mouse testis and epididymis. Differentiation 27:74-81

Liguoro A, Prisco M, Mennella C, Ricchiari L, Angelini $\mathrm{F}$ and Andreuccetti P (2004): Distribution of terminal sugar residues in the testis of the spotted ray Torpedo marmotrata. Mol Reprod and Develop 68, 524-530

Malmi R, Frojdman K and So"derstro"m KO. (1990): Differentiation related changes in the distribution 
glycoconjugates in rat testis. Histochemis-try; 94 :

387-395.

Martinez-Menargues, J. A., Abascal I., Aviles M., Castells M.T., and Ballesta J. (1999): Cytochemical and western blot analysis of the subcompartmentalization of the acrosome in rodents using soybean lectin. Histochem. J. 31, 29-37.

Matthews LH (1950): Reproduction in the basking shark. Cetorhinus maximus (Gunner). Philos Trans R Soc Lond 234: 247316

Mendis-Handagama SM (1997):

Luteinizing hormone on

Leydig cell structure and function. Histology and Histopathology 12, 869-882

Montkowski, A. (1992):

Lichtmikroskopische,ultrastru kturelle, und glykohistochemische Untersuchungen am Hoden des Hundes. Thesis, Institute of Veterinary Anatomy II, Faculty of Veterinary Medicine, LMU ,Munich, Germany

Parson GR and Grier HJ (1992):

Seasonal changes in shark testicular structure and spermatogenesis. J Exp Zool 261, 173-184

Pearse A. (1985): Histochemistry, theoretical and applied, 4th ed, vol 2. Churchill Livingstone, Edinburg.

Pinart, E., Bonet S., Briz M., Pastor L. M., Sancho S., Garcìa N., Badia E., and Bassol J. (2001): Lectin affinity of the seminiferous epithel-ium in healthy and cryptorchid postpubertal boars. Int. J. Androl. 24, 153-164.
Pinart, E., Bonet S., Briz M., Pastor L. M., Sancho S., Garcìa N., Badia E., and Bassol J. (2002): Histochemical study of the interstitial tissue in scrotal and abdominal boar testes. Vet. J. 163, 68-76.

Pratt HL (1988): Elasmobranch gonad structure: a description and survey. Copeia 3: 719-729

Pudney J. and Callard GV (1984a): Development of a granular reticulum in Sertoli cells of the testes of the dogfish Squalus acanthias during spermatogenesis. Anat Rec 209: 311-321

Pudney J. and Callard GV (1984b): Identification of Leydig-like cells in the testis of the dogfish Squalus acanthias. 209: 323-330

Roth J (1966): Protein glycosylation in the endoplasmic reticulum and Golgi apparatus and cell type specificity of cell surface glycoconjugate expre-ssion: analysis by the protein A-gold and lectin-gold techniques. Histo-chemistry and Cell Biology 106, 79-92

Saez FJ, Madrid JF, Aparicio R, Hernandez $F$ and Alonso $E$ (2001a): Carbohydrates moieties of the interstitial and glandular tissues of the amphibian Pleurodeles walt testis shown by lectin histochemistry. Journal of Anatomy 198:47-56

Saez FJ, Madrid JF, Alonso $E$ and Hernandez F (2001b): Glycan composition of follicle (sertoli) cells of the amphibian Pleurodeles waltl. A lectin histochemical study. Journal of Anatomy 198: 673-681chung 75 , 
Soderstrom KO, Malmi $\mathrm{R}$ and Karjalainen K. (1984):

Binding of fluorescein isothiocyanate conjugated lectins to rat spermatogenic cells in tissue section. Enhancement of lectin fluorescence obtained by fixation in Bouin's fluid Histochemistry; 80:575-9.

Spicer S.S. and Schulte B.A. (1992): Diversity of cell glycolconjugates shown histochemicaIly: a perspective. J. Histochem. Cytochem. 40, 1-38.

Stanley HP (1966): The structure and development of the seminiferous follicle in Scyliorhinus canicula and Torpedo marmorata (Elasmobranchii) Zeitschrift fur Zellfors 453468

Teshima K (1981): Studies on thr reproduction of the Japanese smooth dogfish, Mustelus manazo and Mustelus griseus. J Shimonoscki Univ. Fish 29:113-199

Verini-Supplizi, A., Stradaioli G., Fagioli

O. and Prillo F. (2000):

Localization of the lectin reactive sites in adult and prepubertal horse testes. Res. Vet. Sci. 69, 113-118.

Wine R. N. and Chapin R. E. (1997): Evaluation of the binding patterns of eleven FITCconjugated lectins in fischer 344 rat testes. J. Androl. 18, 71-79

Wollina V, Schreiber G, Zollmann C, Hipler C and Gunther E. (1989): Lectin-binding sites in normal human testis. Andrologia ; 21:127-30.

Wourms JP (1977): Reproduction and development in chondrichthyan fishes. Am Zool, 17: 379-410

Ziak M, Qu B, Zuo X, Zuber C, Kanamori $\mathrm{K}$ and Kitajima $\mathrm{K}$ (1996): Occurance of poly $\alpha-$ 2,8-deaminoneuraminic acid (KDN) in mammalian tissues: widespread and developmentally regulated but highly selective expression on glycolproteins. Proceeding of the National Academy of Science of the USA 93, 27592763

Fig. (1):

Panel A, Photograph of the Brown-banded bamboo shark.

Panel B, demonestrates the position of the testes after dissection of the shark (arrow heads).

Panel C, photomicrograph of the testis, showing the Capsule ( $\mathrm{C}$ ), connective tissue septa ( $T$ ), germinal zone (G) and spermatogonial zone (S), H\&E, bar $50 \mathrm{u}$.

Panel D, showing germinal (G) and spermatogonial (S) zones, H\&E , bar $50 \mu$.

Panel E, germinal zone of the testis showing spermatogonia ( white arrow) and Sertoli calls ( black arrow), H\&E, bar $5 \mu$.

Panel F, showing spermatogonial (S) and spermatocyte zone(SC) with connective tissue septa in between the lobes (CT), H\&E, bar $50 \mu$.

Panel G, showing spermatozoal zone with its spermatocystes (SZ), degenerative zone(D), Leydig cells (L) and intratesticular duct (black arrow), PAS, bar $20 \mu$.

Panel $\mathbf{F}$, high magnification to the previous panel showing spermatocyst (SZ) and elongated sperm neuclei (DS), PAS, bar $20 \mu$. 

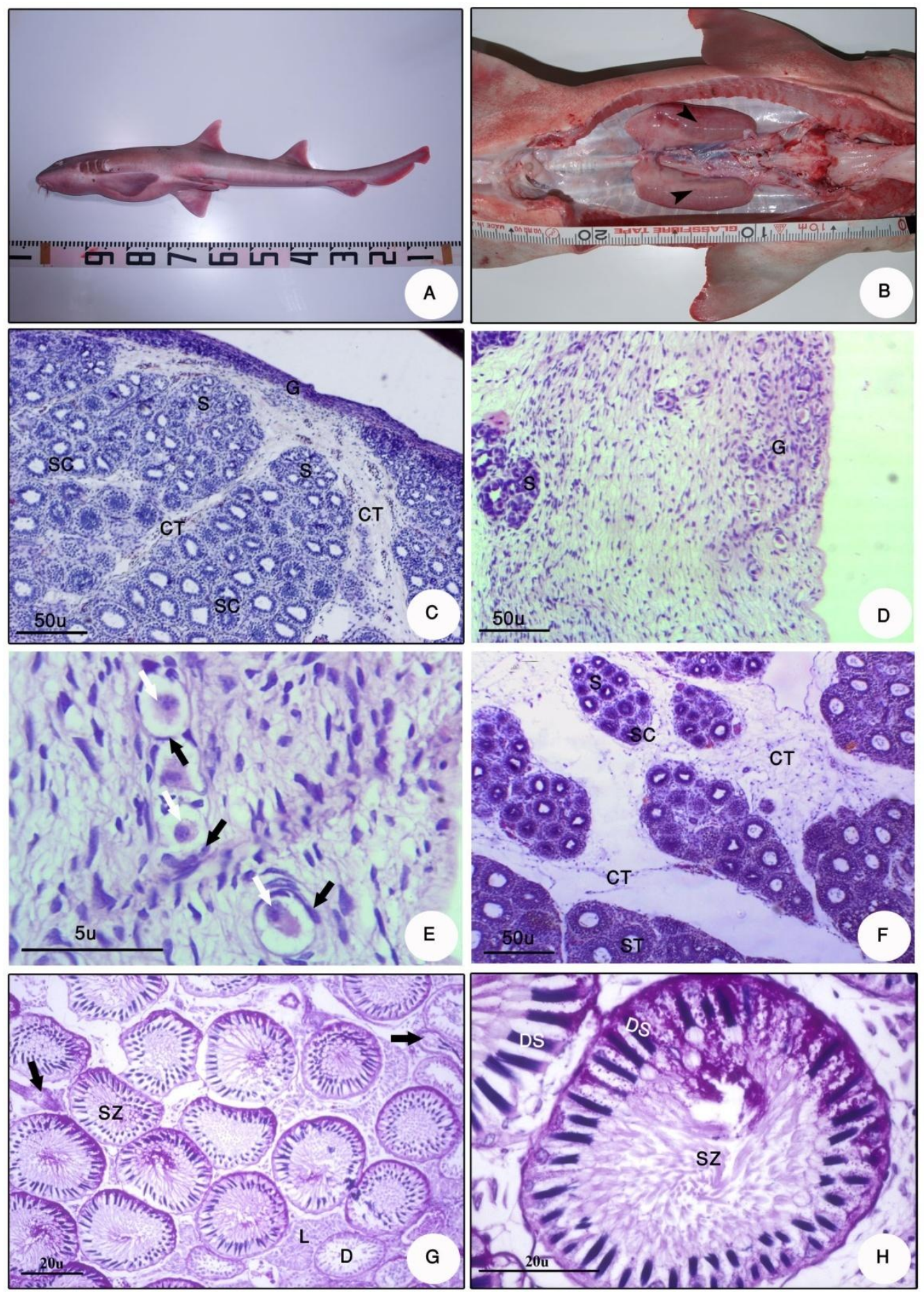

J. Vet. Anat. 
Fig. (2):

Panel A, DBA labeling to the nucleus (black arrows) in the spermatocyst (S) of the spermatogonial zone, bar $5 \mu$.

Panel B, ConA labeling to the interstitial tissue of spermatide zone (black arrow) in between the spermatocysts (SD), bar $20 \mu$.

Panel C, ConA labeling to the interstitial tissue of spermatide zone (black arrows) in between the spermatocysts (SD), bar $20 \mu$.

Panel D, PNA unlabelled to the spermatid zone, bar $20 \mu$.

Panel E, ConA labeling to the elongated sperm (black arrow) in the spermatocyst (SZ) of spermatozoal zone and leydig cells $(\mathrm{L})$, bar $20 \mu$.

Panel F, LCA weak labeled the spermatoblast, heads and tails of the sperm in spermatocyst of spermatozoal zone (SZ), although high labeling to the leydig cells (Black arrows) with the presence of unlabelled intratesticular duct (arrow head), bar $20 \mu$.

Panel G, PNA high labeled to the head of sperm only ( Black arrows) in the spermatocyst of spermatozoal zone (SZ), and weak labeling to the leydig cells (L), bar $20 \mu$.

Panel H, UEA moderate labeled to the tail of sperm (arrow head) and leydig cells $(L)$ in between the spermatocyst (SZ) of spermatozoal zone, bar $20 \mu$. 

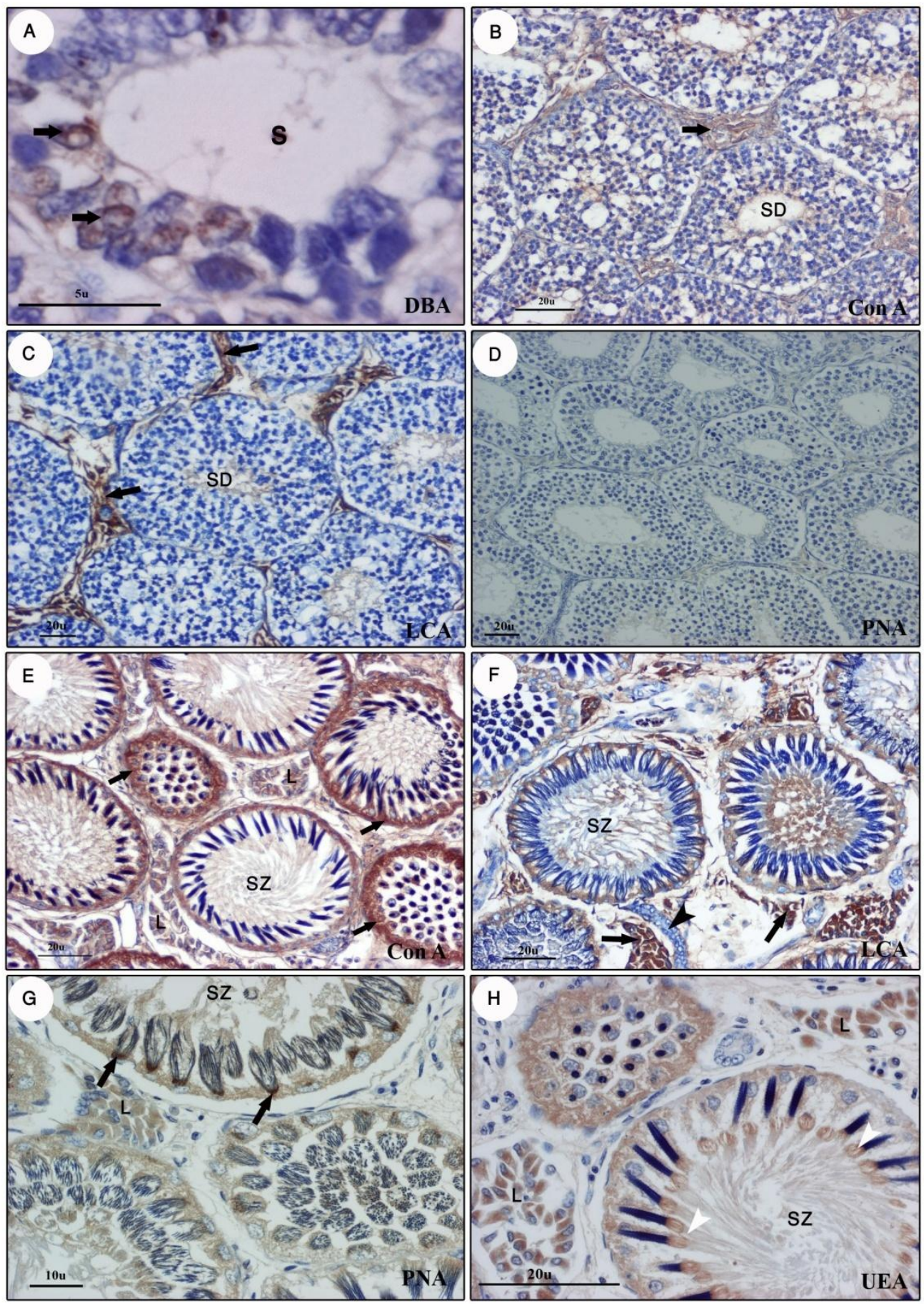

J. Vet. Anat. 
Fig. (3):

Panel A, PHA labeling to the tail of the sperm (white arrow) and spermatoblasts (black arrow ) in the spermatocyst (SZ) of spermatozoal zone, also strong labeling to the leydig cells $(\mathrm{L})$, bar $10 \mu$.

Panel B, LCA labeling to the degenerative zone spermatocysts (DZ) and high labeling to the leydig cells $(L)$, notice the negative labeling of the spermatocyst of spermatozoal zone (SZ) at the junction with the degenerative zone, bar $50 \mu$.

Panel C, ConA labeling to the evacuated spermatocyst of the degenerative zone (DZ) with high labeling to the degenerated cells and also high labeling to the leydig cells $(L)$,

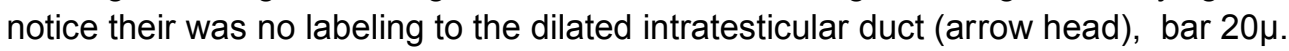

Panel D, PNA labeling to the degenerative zone at the junction with the epigonal organ (EO). Notice the labeling was restricted to the leydig cells only (L) but not to the evacuated spermatocyst (DZ) or to the spermatocyst of the spermatozoal zone (SZ), bar $30 \mu$.

Panel E, High magnification to the previous, bar $10 \mu$.

Panel F, DBA labeling to the Leydig cells only ( $L$ ) and negative for evacuated spermatocyst (DZ), bar $20 \mu$. 

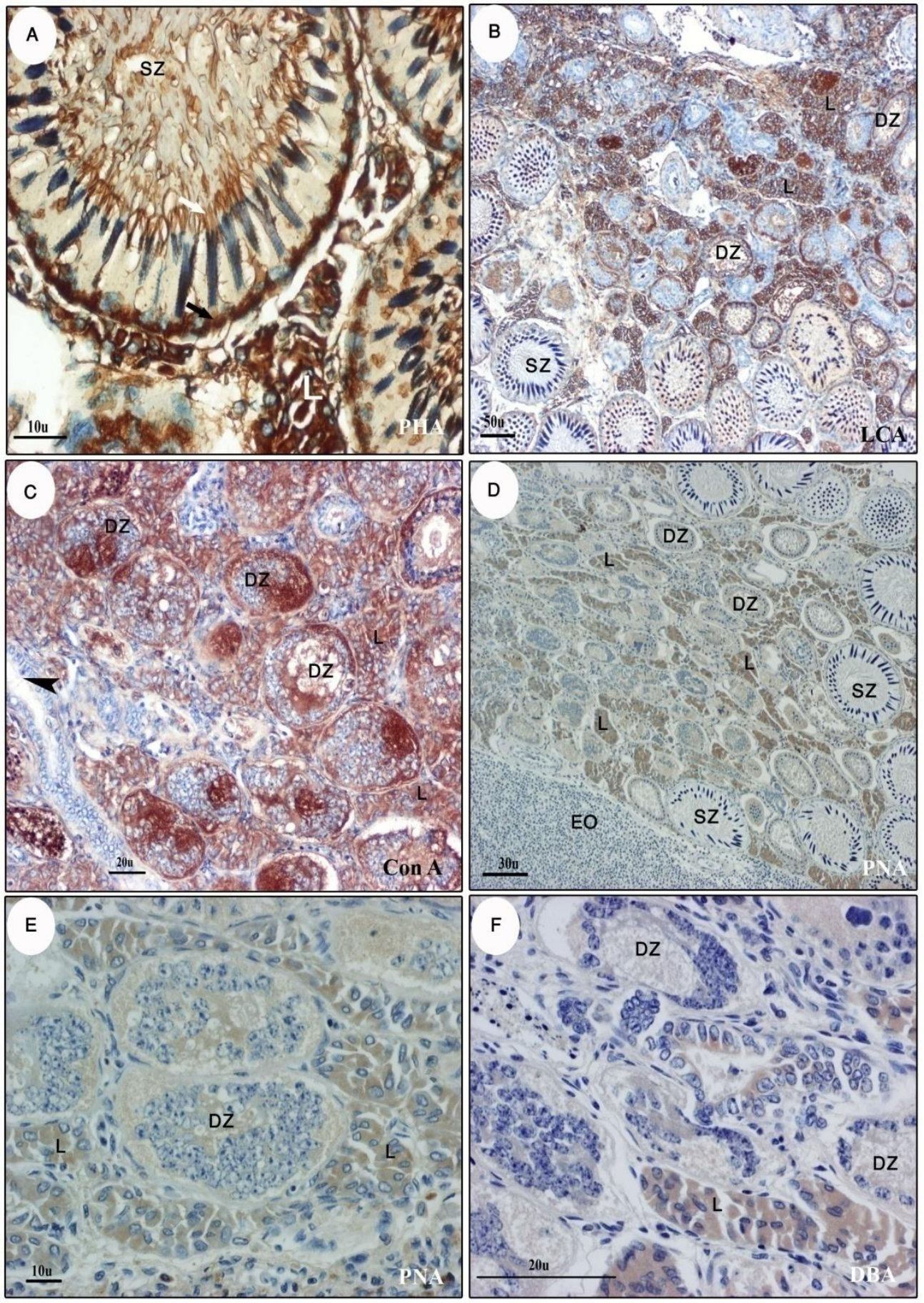